\title{
MULTIPARTED, APOCARPOUS FLOWERS FROM THE EARLY CRETACEOUS OF EASTERN NORTH AMERICA AND PORTUGAL
}

\author{
This paper is dedicated to the memory of our good friend and colleague, Zlatko Kvaček, a world leading palaeobotanist and a respectful, \\ engaging mentor.
}

\author{
ELSE MARIE FRIIS ${ }^{1,2,}$, PETER R. CRANE ${ }^{3,4}$, KAJ RAUNSGAARD PEDERSEN ${ }^{1}$ \\ ${ }^{1}$ Department of Geoscience, University of Aarhus, Høegh-Guldbergs Gade 2, DK-8000 Aarhus C, Denmark; \\ e-mails: else.marie.friis@geo.au.dk, else.marie.friis@nrm.se,krp@geo.au.dk. \\ 2 Department of Palaeobiology, Swedish Museum of Natural History, Box 50007, SE-104 05 Stockholm, Sweden. \\ ${ }^{3}$ Oak Spring Garden Foundation, 1776 Loughborough Lane, Upperville, Virginia 20184, USA; e-mail: peter@osgf.org. \\ ${ }^{4}$ Yale School of the Environment, Yale University, New Haven, Connecticut 06511, USA. \\ ${ }^{*}$ corresponding author
}

Friis, E. M., Crane, P. R., Pedersen, K. R. (2020): Multiparted, apocarpous flowers from the Early Cretaceous of eastern North America and Portugal. - Fossil Imprint, 76(2): 279-296, Praha. ISSN 2533-4050 (print), ISSN 2533-4069 (on-line).

\begin{abstract}
Three new genera, Atlantocarpus, Lambertiflora and Mugideiriflora, are described from the Early Cretaceous of North America and Portugal based on floral structures with multicarpellate and apocarpous gynoecia that have been studied using scanning electron microscopy and synchrotron radiation X-ray tomographic microscopy. Lambertiflora and Mugideiriflora have numerous perianth parts in several series, as well as many stamens and many carpels borne on a short conical receptacle. Atlantocarpus has many carpels arranged spirally on an elongated receptacle. Perianth and stamens are not preserved in Atlantocarpus, but scars of two sizes at the base of the receptacle indicate the presence of several series of tepals and stamens. Phylogenetic assessment of the three new genera indicates close relationships with members of extant Austrobaileyales, which is also favoured by the apparently ascidiate carpels of Atlantocarpus. However, the phylogenetic signal is not strong and the fossils also share many features with magnoliid angiosperms. Fully secure resolution of their relationships is hampered by lack of information of critical floral features in the fossil material, the constellation of likely plesiomorphic characters that they exhibit, and inadequate knowledge of character homologies and character evolution among extant taxa. There is also the broader concern about whether phylogenetic patterns can be reliably inferred for the earliest phases of angiosperm evolution based solely on a depauperate assemblage of extant taxa given extensive extinction over the last 100 million years. The new genera add to growing evidence of diverse extinct angiosperms with multiparted flowers during the Early Cretaceous that have a variety of relationships to extant ANA-grade angiosperms and magnoliids.
\end{abstract}

Key words: apocarpous, Cretaceous, early angiosperms, fossil flowers, multiparted, Potomac Group, SRXTM, synchrotron radiation X-ray tomographic microscopy

Received: August 19, 2020 | Accepted: November 10, 2020 | Issued: December 30, 2020

\section{Introduction}

The study of small structurally preserved flowers, fruits, seeds and stamens from Early Cretaceous (Barremian Albian) deposits in eastern North America and Portugal continues to reveal diverse extinct taxa related to ANA-grade angiosperms (Amborella-Nymphaeales-Austrobaileyales), Chloranthaceae and magnoliid angiosperms (e.g., Friis et al. 1994, 1997, 2009, 2011, 2015a, 2017a, 2018a, b, c, d, 2019a, b, c, 2020a, 2021, von Balthazar et al. 2007, 2008, 2011). Floral structures of eudicot angiosperms, which comprise about three-quarters of extant angiosperm species (Crane and Lidgard 1989, Magallón et al. 1999), are also present in many early mesofossil floras, but are much less common (von Balthazar et al. 2005, Pedersen et al. 2007, Friis et al. 2011, 2017b, 2018e, Mendes et al. 2014).

In terms of their organization and structure, Early Cretaceous angiosperm flowers range from simple forms with few parts, such as the chloranthoids Hedyflora E.M.FrIIS, P.R.Crane et K.R.Pedersen (unisexual) and Canrightiopsis E.M.FriIs, G.W.Grimm, M.M.Mendes et K.R.Pedersen (bisexual), to the more complex bisexual lauralean flowers of Saportanthus E.M.FriIs, P.R.Crane et K.R.Pedersen with multiple parts and a syncarpous gynoecium (Friis 
et al. 2015a, 2017a, 2019c). Also diverse during the Early Cretaceous are numerous multiparted flowers with apocarpous gynoecia. Some of these flowers are represented by multiple specimens and are well preserved (e.g., Friis et al. 2021). Others are known from one or a few specimens and sometimes lack information on critical floral features. Nevertheless, documentation of all the available material is important for a more complete understanding of both the systematic and the structural diversity of angiosperms at this early stage in their evolutionary diversification.

Among the multiparted flowers with apocarpous gynoecia from the Early Cretaceous are the bisexual magnoliid flowers of Melloniflora E.M.FrIIS, P.R.CRANE et K.R.Pedersen from Virginia, USA, and a new taxon from Portugal (Friis et al. 2020a, 2021). In the new taxon floral organs are arranged in whorls, while in Melloniflora they are spiral. Both have apocarpous gynoecia with carpels borne on a flattened receptacle. Here we describe three new genera based on multicarpellate and apocarpous floral structures from the Early Cretaceous in which the carpels are borne on a receptacle that is conical to elongate. All three genera appear most closely related to Austrobaileyales, but also have features indicating possible relationships with Magnoliales.

\section{Material and methods}

The fossil floral structures described here are preserved as three-dimensional coalifications extracted and isolated from unconsolidated sands and clays. One flower is from the Catefica locality, Portugal (S174254, Catefica sample 150), one from the Buarcos locality, Portugal (S105025, Buarcos sample 244), one from the Vale de Água locality, Portugal (S101300, Vale de Água sample 141) and four are from the Puddledock locality, Virginia, USA (PP43700x, Puddledock sample 073; PP43701, Puddledock sample 001; PP43780, Puddledock sample 156; PP53796, Puddledock sample 082).

The Catefica locality is a road cut between the villages of Catefica and Mugideira, near the city of Torres Vedras, on the western margin of the Runa Basin, Portugal (39 $03^{\prime} 16^{\prime \prime} \mathrm{N}$, $\left.09^{\circ} 14^{\prime} 24^{\prime \prime} \mathrm{W}\right)$, which exposes sediments of the Almargem Formation. The age is Early Cretaceous and is estimated as late Aptian-early Albian, or Aptian (for further information and references to locality and age see Friis et al. 2011, 2018e, 2021, Mendes et al. 2020).

The Buarcos locality, in the town of Buarcos, was an exposure of sands, silt and clay in a section along the old road between Buarcos and Tavarede, Portugal ( $40^{\circ} 09^{\prime} 54^{\prime \prime} \mathrm{N}$, $\left.8^{\circ} 52^{\prime} 11^{\prime \prime} \mathrm{W}\right)$ that has now been destroyed by town development. The mesofossils occurred in a small organic rich lens of restricted distribution. The sediments are in the basal part (Calvaria Member) of the Figueira da Foz Formation, which is thought to be of late Aptian to early Albian age (Dinis 2001; for further information and illustration of the Buarcos exposure see also Friis et al. 2011).

The Vale de Água locality is a large complex of clay pits close to the small village of Vale de Água, Portugal $\left(39^{\circ} 37^{\prime} 15^{\prime \prime} \mathrm{N}, 08^{\circ} 51^{\prime} 30^{\prime \prime} \mathrm{W}\right)$ exposing sediments that are also stratigraphically near the base of Figueira da Foz Formation (late Aptian-early Albian; Dinis et al. 2008,
2010). For further information on the locality, see Friis et al. (2011).

The Puddledock locality is a large sand and gravel pit (former Tarmac Lone Star Industries; now Vulcan Materials Co.), south of Richmond and east of the Appomattox River in Prince George County, Virginia, USA ( $37^{\circ} 15^{\prime} 52^{\prime \prime} \mathrm{N}$, $\left.77^{\circ} 22^{\prime} 10^{\prime \prime} \mathrm{W}\right)$. The sediments belong to the Potomac Group sequence and are dated as Early Cretaceous (early to middle Albian) based on palynology (Christopher in Dischinger 1987); for further information and references see also Friis et al. (2011, 2020a).

Mesofossils were extracted from samples collected from all four localities by washing and panning over a $125 \mu \mathrm{m}$ sieve in water, and were then cleaned of adhering mineral matrix with $\mathrm{HF}, \mathrm{HCl}$ and water following standard methods (see Friis et al. 2011, 2018b). Specimens were mounted on brass or aluminum stubs with nail polish for synchrotron radiation X-ray tomographic microscopy (SRXTM) and scanning electron microscopy (SEM).

Synchrotron radiation X-ray tomographic microscopy (SRXTM) was carried out at the TOMCAT Beamline, Swiss Light Source at the Paul Scherrer Institute, Villigen, Switzerland (Stampanoni et al. 2006). The analyses were absorption based and the measurements done with rotation over $180^{\circ}$ (PP43780, PP53796) or laterally stacked over $360^{\circ}$ (S174254). Specimen S174254 was analysed at $10 \mathrm{keV}$ using a $10 \times$ objective with isotopic pixel size of $0.65 \mu \mathrm{m}$, a sCMOS detector and a $20 \mu \mathrm{m}$ thick LuAg:Ce scintilator screen. Specimens PP43780 and PP53796 were analysed at $10 \mathrm{keV}$ using a $10 \times$ objective with isotropic pixel size of $0.74 \mu \mathrm{m}$, a sCMOS detector and a $13 \mu \mathrm{m}$ thick YAG:Ce scintillator screen. For details on SRXTM work on Cretaceous plant mesofossils at TOMCAT see Friis et al. (2014). Data derived from the SRXTM scans were analysed and manipulated using Avizo software (9.1.1-9.5; Thermo Scientific, Waltham, MA, USA) for computed tomography.

Scanning electron microscopy (SEM) was carried out using a Phillips 515 scanning electron microscope (S101300, S105025, PP43700x, PP43701) or Hitachi S-4300 field emission microscope (S174254, PP43780, PP53796) at the Swedish Museum of Natural History. The specimens were coated with gold (thickness not measured). Photoshop CS5 Adobe (San Jose, CA, USA) was used to create an even black background for SEM images and to label SRXTM orthoslices.

Phylogenetic assessment of the fossils was performed by adding their morphological characters to the morphological dataset constructed by Doyle and Endress (2000, 2014) for early diverging extant angiosperms. The data were analysed using Mesquite software version 3.2 (Maddison and Maddison 2017) and the Parsimony Ancestral State feature with all characters treated as unordered. The number of character state changes for each potential position was recorded by linking the fossils manually to all possible branches of the Doyle and Endress (D\&E) backbone tree, which is constrained to the topology for extant taxa based on molecular data (Doyle and Endress 2000, 2014).

The fossil specimens are housed in the palaeobotanical collections of the Field Museum, Chicago (PP) and in the Swedish Museum of Natural History, Stockholm (S). Raw data from the SRXTM analyses are available at the PSI Public Data Repository, Paul Scherrer Institute, Villigen, 
Switzerland (Friis et al. 2020b). The names assigned to the new genera and species described here, each with a unique registry number, are registered in the Plant Fossil Names Registry, which is hosted and operated by the National Museum, Prague for the International Organisation of Palaeobotany (IOP).

\section{Characters scored for the fossil taxa}

Characters were scored for the fossils as follows using the character definitions and numbering of Doyle and Endress (2000, 2014).

Twenty-six morphological characters were scored for Mugideiriflora portugallica E.M.FrIIS, P.R.CRANE et K.R.Pedersen gen. et sp. nov.: 47. Sex of flowers (0) bisexual. 48. Floral base (0) hypanthium absent, superior ovary. 49. Floral receptacle (female portion) (1) elongate. 50. Pits in receptacle bearing individual carpels $(0)$ absent. 52. Floral apex (0) used up after production of carpels. 53. Perianth (0) present. 54. Perianth phyllotaxis (0) spiral. 56. Perianth whorls/series (2) more than two. 57. Perianth differentiation (0) all more or less sepaloid. 58. Petals (0) absent. 59. Nectaries on inner perianth parts (0) absent. 60 . Outer perianth parts $(0)$ free. 61. Calyptra derived from last one or two bracteate organs below the flower (0) absent. 62. Stamen number (0) more than one. 63. Androecium phyllotaxis (0) spiral. 65. Number of stamen whorls/ series (2) more than 2. 66. Stamen position (0) single. 67. Stamen fusion (0) free. 68. Inner staminodes (0) absent. 69. Glandular food bodies on stamens or staminodes (0) absent. 70. Stamen base (0) short. 71. Paired basal stamen glands (0) absent. 72. Connective apex (0) extended. 74. Microsporangia (0) four. 96. Carpel number (3) more than one whorls/series. 106. Carpel fusion (0) apocarpous.

Sixteen characters were scored for Lambertiflora elegans E.M.Fris, P.R.Crane et K.R.Pedersen gen. et sp. nov.: 47. Sex of flowers (0) bisexual. 48. Floral base (0) hypanthium absent, superior ovary. 49. Floral receptacle (female portion) (1) elongate. 50. Pits in receptacle bearing individual carpels (0) absent. 52. Floral apex (0) used up after production of carpels. 53. Perianth (0) present. 54. Perianth phyllotaxis (0) spiral. 56. Perianth whorls/series (2) more than two. 57. Tepal differentiation (0) all more or less sepaloid. 58. Petals (0) absent. 60. Outermost perianth parts (0) free. 61. Calyptra derived from last one or two bracteate organs below the flower (0) absent. 62. Stamen number (0) more than one. 63. Androecium phyllotaxis (0) spiral. 96. Carpel number (3) more than one whorls/series. 106. Carpel fusion (0) apocarpous.

Sixteen characters were scored for Atlantocarpus virginiensis E.M.FrIIS, P.R.CRANE et K.R.PEDERSEN gen. et sp. nov.: 47. Sex of flowers (0) bisexual. 48. Floral base (0) hypanthium absent, superior ovary. 49. Floral receptacle (female portion) (1) elongate. 50. Pits in receptacle bearing individual carpels (0) absent. 52. Floral apex (0) used up after production of carpels. 53. Perianth (0) present. 60. Outer perianth parts $(0)$ free. 61. Calyptra derived from last one or two bracteate organs below the flower (0) absent. 62 . Stamen number (0) more than one. 66. Stamen position (0) single. 67. Stamen fusion (0) free. 96. Carpel number (3) more than one whorls/series. 97. Carpel form (0) ascidiate up to stigma. 101. Style (0) absent. 102. Stigma (0) extended. 106. Carpel fusion (0) apocarpous.

\section{Systematic palaeobotany}

Subdivision Angiospermae LindL., 1830

\section{Genus Mugideiriflora E.M.FriIS, P.R.Crane et K.R.Pedersen gen. nov.}

Ty p e. Designated here. Mugideiriflora portugallica E.M.FriIs, P.R.Crane et K.R.Pedersen gen. et sp. nov.

Plant Fossil Names Registry Number. PFN000906 (for new genus).

Ety m o log y. From the village of Mugideira close to where the fossil was collected.

Diagnos is. Flower structurally bisexual, with multiparted perianth, androecium and gynoecium. Floral receptacle flat to slightly concave but conical in the pistillate region. Phyllotaxis of floral organs apparently spiral. Perianth of about 50 tepals in several series. Tepals broad with transversely elongate and rhomboidal bases. Androecium of more than 50 stamens in several series. Stamens with short bases, poorly differentiated from the anther, rhomboidal in transverse section. Anthers dithecate and tetrasporangiate with an expanded and slightly pointed connective apex. Pollen sacs in a lateral position. Gynoecium superior, apocarpous, of more than 50 free carpels borne in several series on the conical gynoecial portion of the receptacle.

Comments on the genus. The flower of Mugideiriflora portugallica is open and apparently preserved at a young anthetic stage with a large number of immature stamens and carpels, which distinguishes it from most other multiparted flowers described from the Cretaceous (see Discussion for further comparison and references). The fossil cannot be assigned to any extant family or to any fossil taxon described so far (see Discussion).

Mugideiriflora is distinguished from Lambertiflora, described here from the Puddledock locality, by its much broader perianth parts and the greater number of parts in perianth, androecium and gynoecium. It is also distinguished from Atlantocarpus virginiensis E.M.FrIIS, P.R.CRANE et K.R.PEDERSEN from the Puddledock locality and Atlantocarpus sp. from the Buarcos locality by the short, conical gynoecial portion of the receptacle. Atlantocarpus, as well as two other multicarpellate floral structures, Reyanthus lusitanicus E.M.Fris, P.R.Crane et K.R.Pedersen and Choffaticarpus compactus E.M.Fris, P.R.Crane et K.R.Pedersen first described from the Torres Vedras locality have receptacles that are strongly elongated (Friis et al. 2019a). Mugideiriflora is also distinct from another new multiparted flower from the Catefica locality (Friis et al. 2021) in its greater number of parts, the spiral phyllotaxis of all organs, and the conical floral receptacle in the gynoecial zone.

\section{Mugideiriflora portugallica E.M.Fris, P.R.CrANE et K.R.Pedersen sp. nov. Text-figs 1a-f, 2a-g}

Holotype. Designated here. S174254 (Catefica sample 150; figured Text-figs 1a-f, 2a-g).

Plant Fossil Names Registry Number. PFN000907 (for new species). 



Text-fig. 1. Scanning electron micrographs of Mugideiriflora portugallica gen. et sp. nov. from the Early Cretaceous Catefica locality, Portugal (holotype, S174254, Catefica sample 150). a) Flower in oblique lateral view showing numerous broad tepals, numerous inwardly curved stamens and the flat floral receptacle with a conical gynoecial region; b-c) Flower in two different oblique apical views showing numerous broad laminar tepals and inwardly curved stamens surrounding the carpels; note cellular differences between outer (op) and inner (in) perianth parts, as well as bases of anthers, apparently with laterally to slightly dorsally placed pollen sacs (arrow heads); d) Detail of flower showing a cluster of poorly differentiated carpels in the center surrounded by elongated stamens; note grooves in the dorsal surface of the stamens indicating the position of the pollen sacs; e) Detail of flower showing the broad bases of the laminar tepals, rhomboidal stamen bases and poorly differentiated carpels; f) Detail of flower showing inwardly arched stamens and poorly differentiated carpels. Scale bars $=1 \mathrm{~mm}(\mathrm{a}-\mathrm{c}), 200 \mu \mathrm{m}(\mathrm{d}-\mathrm{f})$.

Repos it ory. Palaeobotanical Collections, Swedish Museum of Natural History, Stockholm, Sweden (S).
Etymology. From Portugal where the fossil was collected. 
Type locality. Catefica $\left(39^{\circ} 03^{\prime} 16^{\prime \prime} \mathrm{N}\right.$, $\left.09^{\circ} 14^{\prime} 24^{\prime \prime} \mathrm{W}\right)$, between the villages of Catefica and Mugideira, about $4 \mathrm{~km}$ south of Torres Vedras, Portugal.

Type stratum and age. Almargem Formation, Early Cretaceous (Aptian-early Albian).

Di a g nos is. As for the genus.

D i m e n s i o n s. Length of flower: $1.1 \mathrm{~mm}$ (full length not preserved; estimated full length about $2 \mathrm{~mm}$ ); diameter: $1.75 \mathrm{~mm}$.

Description and remarks. The species is based on a single, slightly abraded flower (S174254) and two small flower fragments from the same locality (S174770, S174771, Catefica sample 50). The flower is small, about $1.75 \mathrm{~mm}$ in diameter, open and apparently preserved in a young anthetic stage with stamens and carpels not fully mature (Text-figs 1a-f, 2a-g). The flower is structurally bisexual, with multiparted perianth, androecium and gynoecium (Text-figs $1 \mathrm{a}-\mathrm{f}, 2 \mathrm{a}-\mathrm{g}$ ). The floral receptacle is flat to slightly concave but is extended into a short conical gynoecial zone in the pistillate region (Text-fig. 2b, e, f). The phyllotaxis of all floral organs is apparently spiral (Text-figs $1 \mathrm{a}-\mathrm{c}, 2 \mathrm{c}-\mathrm{e})$. Because the flower is abraded, the total number of floral parts is unknown, but is estimated based on the well-preserved parts of the flower.

The perianth has about 50 tepals in several series. The tepals are broad with correspondingly broad, transversely elongate and narrowly rhomboidal bases. The tepals are composed of thin-walled, equiaxial cells. The tepals of the outer one or two series are covered by a thin cuticle (Textfig. 2c, d) while those of the inner three or four series have a thick cuticle on their outer surface over a layer of epidermal cells that also appear to be thick-walled (Text-fig. 2c, d).

The androecium consists of more than 50 stamens in about four series (Text-fig. 2b-e). Each stamen has a short, broad base that is poorly differentiated from the anther and that is rhomboidal in transverse section (Text-fig. 2d, e). The anthers are apparently dithecate and tetrasporangiate with an expanded and slightly pointed connective apex. The pollen sacs appear to be embedded in a lateral to slightly dorsal position. The mode of dehiscence is not clear. No pollen has been observed.

The gynoecium is superior, apocarpous and consists of more than 50 free carpels borne on the conical gynoecial portion of the receptacle in several series (Text-fig. 2b, $\mathrm{e}-\mathrm{g}$ ). The carpels appear ascidiate, but because the flower is preserved at a very young stage, the nature of the carpels is not completely certain.

\section{Genus Lambertiflora E.M.Fris, P.R.Crane et K.R.Pedersen gen. nov.}

Type. Designated here. Lambertiflora elegans E.M.Fris, P.R.Crane et K.R.Pedersen gen. et sp. nov.

Plant Fossil Names Registry Number. PFN000904 (for new genus).

Ety mology. In honour of Rachel Lambert Mellon (1910 - 2014) for her strong engagement and support of plants and environment in Virginia where the fossil was collected.
Di a g nos is. Flower structurally bisexual, with multiparted perianth, androecium and gynoecium. Floral receptacle conical, elongate. Perianth of about 30 tepals spirally arranged in several series. Tepals all sepaloid and free from each other, narrowly elongate with rhomboidal bases. Androecium of several free stamens, apparently spirally arranged in at least two series. Gynoecium apocarpous, of many free carpels borne on the conical receptacle; ovary superior. Large, secretory cells in all floral tissues.

Comments on the genus. The flower of Lambertiflora is preserved in a pre-anthetic stage with androecium and gynoecium not fully differentiated. Lambertiflora is distinguished from all other multiparted flowers described from the Cretaceous by its long, narrow tepals. It is similar to Mugideiriflora in its conical receptacle that is elongated in the gynoecial zone, and its spirally arranged perianth parts, but Lambertiflora differs in having tepals of only one kind, whereas Mugideiriflora has differentiated tepals. Lambertiflora is distinguished from Atlantocarpus by its much shorter receptacle and its greater number of tepals. Lambertiflora differs from the two other multiparted flowers described previously from the Puddledock mesofossil flora, Melloniflora virginiensis E.M.Fris, P.R.Crane et K.R.Pedersen and Virginianthus calycanthoides E.M.FriIS, H. EKLUND, K.R.PEDERSEN et P.R.CRANE, by its conical floral receptacle that is elongated in the gynoecial zone. In Melloniflora virginiensis the floral receptacle is flat while in Virginianthus calycanthoides it forms a distinct cup. For further comparison and references, see Discussion.

\section{Lambertiflora elegans E.M.FrIIS, P.R.CRANE et K.R.Pedersen sp. nov. \\ Text-figs $3 \mathrm{a}-\mathrm{e}, 4 \mathrm{a}-\mathrm{c}$}

Hol oty pe. Designated here. PP53796 (Puddledock sample 082; figured Text-figs 3a-e, 4a-c).

Plant Fossil Names Registry Number. PFN000905 (for new species).

R e p o s i t o r y. Paleobotanical Collections, Department of Geology, Field Museum, Chicago, Illinois, USA (PP). fossil.

E ty m o logy. From the slender, elegant shape of the

Type locality. Puddledock, former Tarmac Lone Star Industries (Vulcan Materials) sand and gravel pit, located south of Richmond and east of the Appomattox River in Prince George County, Virginia, USA (37 $15^{\prime} 52^{\prime \prime} \mathrm{N}$, $\left.77^{\circ} 22^{\prime} 10^{\prime \prime} \mathrm{W}\right)$.

Type stratum and age. Basal part of Subzone IIB, Potomac Group; Early Cretaceous (early to middle Albian).

Di a gnosis. As for the genus.

D i m e n s i o n s . Length of flower bud (stalk excluded): $1.3 \mathrm{~mm}$; diameter: $0.75 \mathrm{~mm}$.

Description and remarks. The species is based on a single, charcoalified, three-dimensionally preserved flower bud (Text-figs $3 a-e, 4 a-c$ ). The bud is borne on 

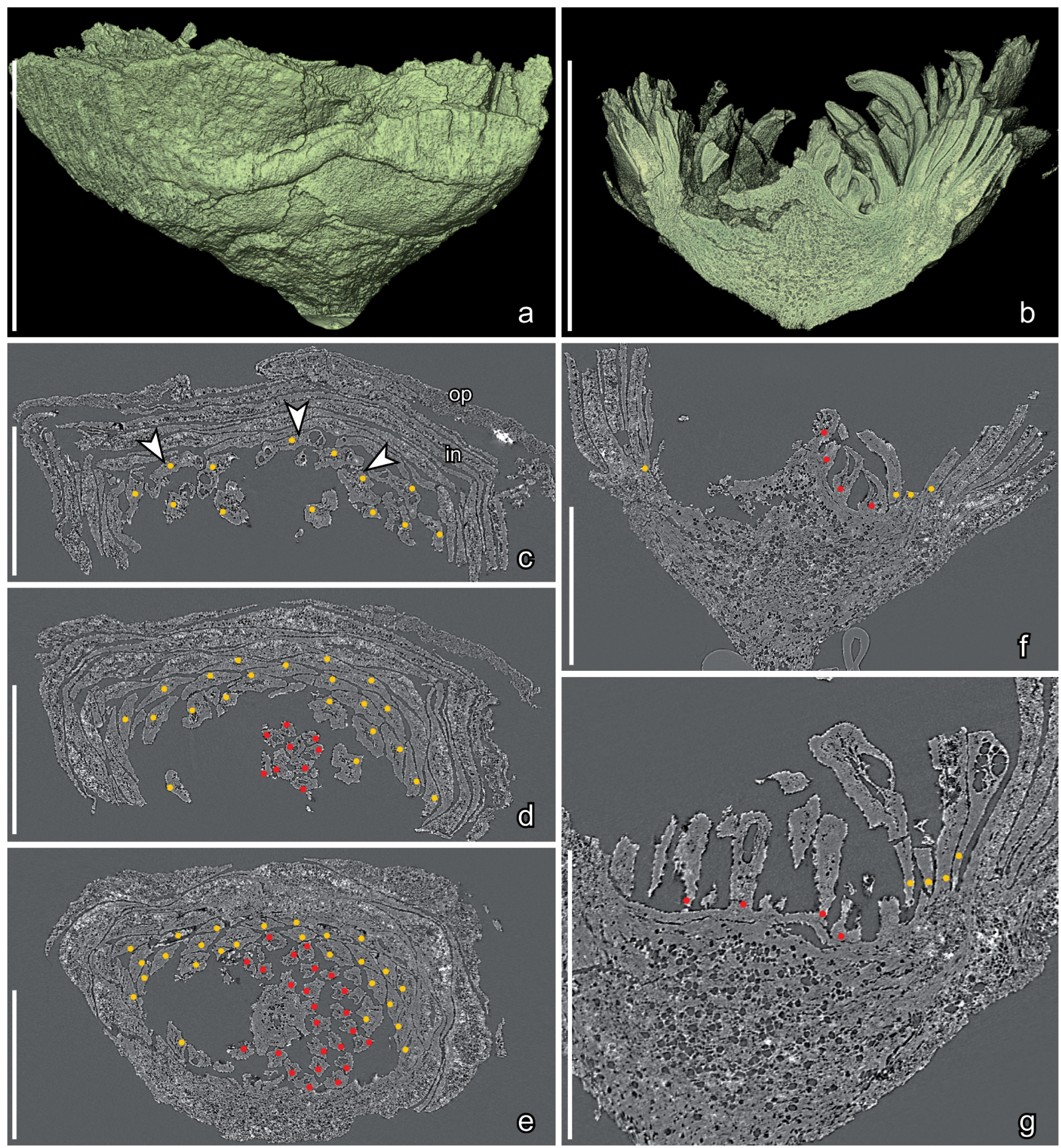

Text-fig. 2. Synchrotron radiation X-ray tomographic microscopy volume renderings (a, b) and orthoslices (c-e) of Mugideiriflora portugallica gen. et sp. nov. from the Early Cretaceous Catefica locality, Portugal (holotype, S174254, Catefica sample 150). Yellow dots - stamens, red dots - carpels. a) Flower in lateral view showing the broad bases of the laminar tepals; b) Flower in longitudinal section showing the flat to slightly concave floral receptacle with a central conical gynoecial region (cut between orthoslices yz0800 and 1220); c) Flower in transverse section showing the numerous laminar tepals in several series and the stamens cut in the region of the poorly differentiated anthers; note cellular differences between outer (op) and inner (in) perianth parts, as well as and transverse sections of anthers, apparently with laterally to slightly dorsally placed pollen sacs (arrow heads) (cut at orthoslice xy0770); d) Flower in transverse section showing the numerous laminar tepals in several series, flattened rhomboidal stamen bases in several series, and poorly differentiated carpels (cut at orthoslice xy0820); e) Flower in transverse section showing the numerous laminar tepals in several series, flattened rhomboidal stamen bases in several series, and poorly differentiated carpels (cut at orthoslice xy0920); f) Flower in longitudinal section showing the shallowly concave floral receptacle with laminar tepals, stamens, and a central conical gynoecial region bearing poorly differentiated carpels (cut at orthoslice yz0900); g) Flower in longitudinal section perpendicular to that in (f) showing stamens and poorly differentiated carpels (cut at orthoslice xz1630). Scale bars =1 mm (a, b), $500 \mu \mathrm{m}(\mathrm{c}-\mathrm{g})$. 

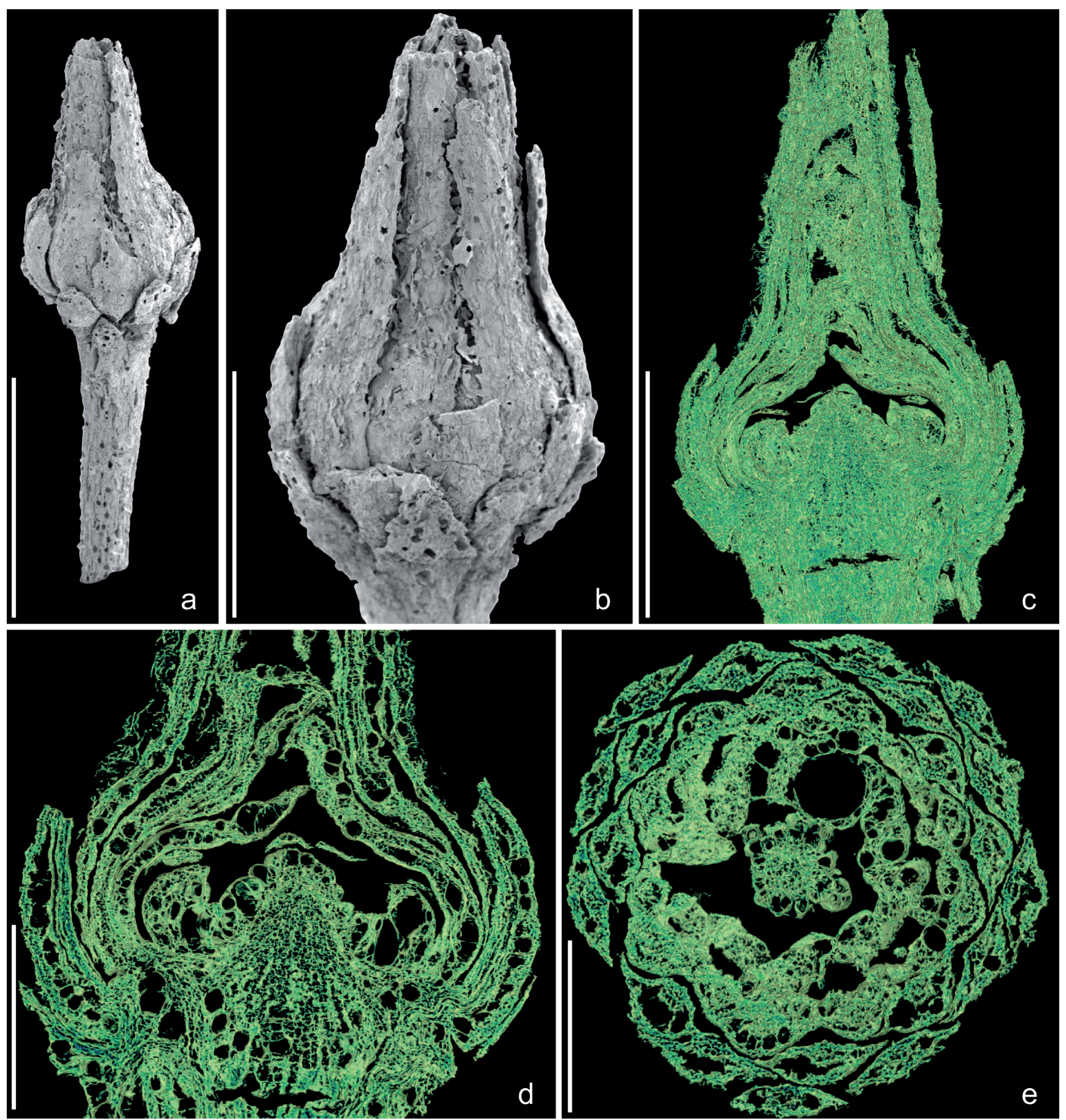

Text-fig. 3. Scanning electron micrographs (a, b) and synchrotron radiation X-ray tomographic microscopy orthoslices (c-e) of flower of Lambertiflora elegans gen. et sp. nov. from the Early Cretaceous Puddledock locality, Virginia, USA (holotype, PP53796, Puddledock sample 082). a) Flower in lateral view showing long pedicel and overlapping elongated tepals; b) Detail of flower showing overlapping elongated tepals; note the numerous holes indicating the position of probable secretory cells; c) Flower in longitudinal section showing overlapping elongated tepals, remains of probable poorly developed stamens or staminodes and probable poorly developed carpels on the central conical gynoecial region of the receptacle (cut between orthoslices xz0510 and 0570); d) Flower in longitudinal section (comparable to c) showing overlapping tepals, poorly developed stamens or staminodes, and probable poorly developed carpels on the central conical gynoecial region of the receptacle; note the prominent cavities from secretory cells scattered through the tissues (cut between orthoslice xz0560 and 0575); e) Flower in transverse section showing overlapping tepals, poorly developed stamens or staminodes, and remains of probable poorly developed carpels (cut between orthoslices xy1160 and 1180). Scale bars $=1 \mathrm{~mm}(\mathrm{a}), 500 \mu \mathrm{m}(\mathrm{b}-\mathrm{e})$.

a long slender pedicel (Text-fig. 3a) and was probably solitary. It is preserved at an early developmental stage and charcoalification has also caused many of the cell walls to burst. As a result details of the androecium and gynoecium are not clear (Text-figs 3c-e, 4a-c).
The perianth is the best preserved part of the flower bud. It consists of about 30 narrowly elongate tepals with rhomboidal bases (Text-figs 3a-e, $4 \mathrm{a}-\mathrm{c}$ ). Tepals are undifferentiated and arranged spirally, in several series. The androecium consists of many parts, but the early developmental stage at which 


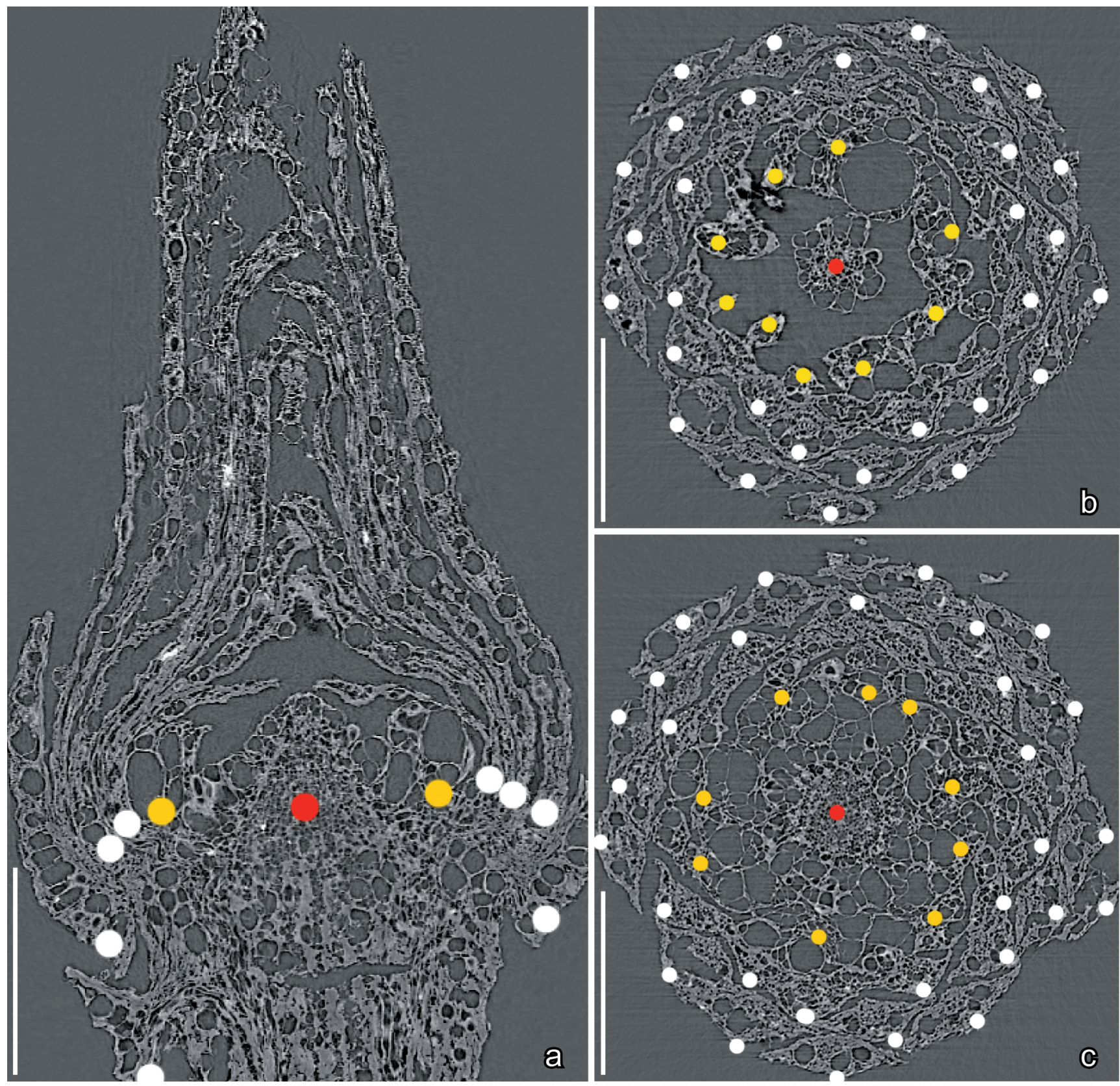

Text-fig. 4. Synchrotron radiation X-ray tomographic microscopy orthoslices of flowers of Lambertiflora virginiense gen. et sp. nov. from the Early Cretaceous Puddledock locality, Virginia, USA (holotype, PP53796, Puddledock sample 081). White dots - tepals, yellow dots - stamens or staminodes, red dot - central conical gynoecial region. a) Flower in longitudinal section showing elongated overlapping tepals, remains of probable poorly developed stamens or staminodes and probable poorly developed carpels on the central conical gynoecial region of the receptacle (orthoslice yz0454); b) Flower in transverse section showing rhomboidal bases of 30 tepals, nine poorly developed stamens or staminodes, and the central poorly differentiated gynoecial region of the receptacle (orthoslice xy1160); c) Flower in transverse section at the level of the floral receptacle showing 30 tepals, nine of the poorly developed stamens or staminodes, and the central poorly differentiated gynoecial region of the receptacle (orthoslice xy1250). Scale bars $=250 \mu \mathrm{m}(\mathrm{a}-\mathrm{c})$.

the flower bud was preserved, together with the nature of the preservation, precludes establishing the precise number of stamens and their arrangement (Text-figs 3c-e, $4 a-c)$. For the same reason, information on anthers and dehiscence mode is also lacking. The gynoecium appears to be preserved only as crowded poorly developed carpels (possible carpel primordia) on the conical receptacle (Text-figs 3d, e, 4a, b).

All tissues of the floral bud contain a number of larger, rounded cells that are probably secretory. These are densely spaced inside the tissues of the floral bud and are also seen on the surface of the tepals and pedicel where the cells have burst open (Text-figs 3d, e, 4a-c).

\section{Genus Atlantocarpus E.M.Fris, P.R.Crane et K.R.Pedersen gen. nov.}

Ty p e. Designated here. Atlantocarpus virginiensis E.M.FriIs, P.R.Crane et K.R.Pedersen gen. et sp. nov.

Plant Fossil Names Registry Number. PFN001600 (for new genus). 
Etymology. From the occurrence of the genus on both sides of the Cretaceous North Atlantic.

Diagnosis. Floral structure bracteate, pedicellate and structurally bisexual, with a multiparted perianth, androecium and gynoecium. Floral receptacle elongate conical. Ovary superior lacking a hypanthium. Perianth of about 15 tepals in two or more series. Tepals with broad rhombic bases. Androecium of about 15 free stamens in two or more series. Gynoecium apocarpous, of about 40 to 50 carpels arranged spirally along the elongated receptacle. Style lacking, stigmatic region extended. Carpels apparently ascidiate.

Comments on the genus. Atlantocarpus is distinguished from Mugideiriflora and Lambertiflora by its strongly elongated receptacle that bears only a few tepals. It also differs from previously described Cretaceous floral structures that also have a strongly elongated receptacle (Archaeanthus linnenbergeri DILCHER et P.R.CRANE; Choffaticarpus compactus and Reyanthus lusitanicus) in its fewer floral parts. The specimen of Atlantocarpus sp. described here from the Buarcos locality was illustrated previously in association with fruits of Anacostia E.M.FrIIS, P.R.Crane et K.R.Pedersen (Friis et al. 1997: fig. 10A-C). Another specimen also associated with Anacostia is from the Puddledock locality and strongly compressed (Friis et al. 1997: fig. 6A-E). This specimen is also multicarpellate and apocarpous and was linked with fruits of Anacostia E.M.FriIS, P.R.CrAne et K.R.PEDERSEN based on abundant Anacostia-type pollen at the base of the floral receptacle. This specimen is similar to Atlantocarpus in general organization. It is, however, distinguished from Atlantocarpus by its larger size and greater number of carpels and we here refer to this fossil as Anacostia? sp. (Text-fig. 6a, b). Another multicarpellate and apocarpous floral structure from Puddledock (Text-fig. 6c) is similar to Anacostia? sp. but three-dimensional. Possibly this specimen and Anacostia? sp. represent different developmental stages of the same kind of plant. Unfortunately, there are no cellular details or pollen that could link the specimens of Atlantocarpus to Anacostia. For further discussion and references, see Discussion.

\section{Atlantocarpus virginiensis E.M.FriIS, P.R.Crane et K.R.Pedersen sp. nov. Text-fig. 5a-d}

Hol otype. Designated here. PP43780 (Puddledock sample 156; figured Text-fig. 5a-d).

Plant Fossil Names Registry Number. PFN001601 (for new species).

R e p o s i t o r y. Paleobotanical Collections, Department of Geology, Field Museum, Chicago, Illinois, USA (PP).

Etymology. From the state of Virginia where the fossil was discovered.

Type locality. Puddledock, former Tarmac Lone Star Industries (Vulcan Materials) sand and gravel pit, located south of Richmond and east of the Appomattox River in Prince George County, Virginia, USA ( $37^{\circ} 15^{\prime} 52^{\prime \prime} \mathrm{N}$, $\left.77^{\circ} 22^{\prime} 10^{\prime \prime} \mathrm{W}\right)$.
Type stratum and age. Basal part of Subzone IIB, Potomac Group; Early Cretaceous (early to middle Albian).

Di a g n o s is. As for the genus.

D i m e n s i o n s. Length of flower bud (stalk excluded): $1.3 \mathrm{~mm}$; diameter: $0.8 \mathrm{~mm}$.

Description and remarks. The flower is terminal on a long stalk that bears at least one bract that is seen as a broad scar on the pedicel (Text-fig. 5a). The flower is preserved at an early developmental stage and somewhat abraded. Tepals and stamens are not preserved, but the presence of carpels, as well as scars from tepals and stamens, show that the floral structure was multiparted and structurally bisexual. Distinct scars of two sizes indicate the presence of about 15 tepals in at least two series and 15 stamens also in at least two series (Text-fig. 5a, b, d). The arrangement of tepals and stamens is otherwise not clear. Tepals have a broad rhomboidal base and were apparently free from each other (Text-fig. 5a, b, d). Remains of stamen bases show that the stamens were free from each other and that each had a broad, flattened base (Text-fig. 5d).

The floral receptacle is conical and strongly elongated with a distinct basal collar (Text-fig. 5a-d). The gynoecium is apocarpous and consists of about 50 carpels, arranged spirally along the elongate floral receptacle. The carpels are broadly attached to the receptacle leaving a rounded scar (Text-fig. 5a). They are slightly flattened laterally with straight ventral and dorsal faces and a slightly expanded stigmatic region that is exposed towards the outer surface of the gynoecium, and sometimes appears grooved and indistinctly bifid (Text-fig. 5d). The surface of the carpel in the probable stigmatic area is irregular, perhaps due to the presence of oil cells (Text-fig. 5c, d). Carpels and ovules are not sufficiently well-preserved to show the organization clearly, but there is no distinct ventral suture visible in the SRXTM orthoslices. The carpels appear ascidiate with only one or two ovules per carpel (Text-fig. 5c).

\section{Atlantocarpus sp.}

Text-fig. 5e, $\mathrm{f}$

1997 Cone-like structure associated with Anacostia at the Buarcos locality; Friis et al., fig. 10.

Description and remarks. A single, multicarpellate floral structure from the Buarcos locality, Portugal (S105025, Buarcos sample 244), closely resembles Atlantocarpus virginiensis from the Puddledock locality.

The specimen is about $1.9 \mathrm{~mm}$ long, $3.2 \mathrm{~mm}$ long including the long stalk (Text-fig. 5e). As in A. virginiensis the floral structure is preserved at an early developmental stage and internal features are not known for this specimen. The remains of tepals are bent over the basal part of the receptacle at the level of the collar obscuring any stamens, if they were present.

The floral receptacle is elongate conical (Text-fig. 5e, f) and the gynoecium is apocarpous consisting of about 40 spirally arranged carpels. The carpels are slightly flattened laterally and slightly swollen at the apex, probably reflecting an expanded stigmatic region. As in Atlantocarpus 



Text-fig. 5. Scanning electron micrographs $(\mathrm{d}-\mathrm{g})$ and synchrotron radiation X-ray tomographic microscopy orthoslices (a-c) of flowers of Atlantocarpus virginiensis gen. et sp. nov. (a-d: holotype, PP43780, Puddledock sample 156), Atlantocarpus sp. from the Early Cretaceous Buarcos locality (e, f: S105025, Buarcos sample 244) and receptacle of Atlantocarpus? from the Early Cretaceous Vale de Água locality (g: S101300, Vale de Água sample 141). a) Flower in lateral view showing scar from a single bract (br), attachment scars of tepals ( $t$ ) and stamens (st) on the expanded basal portion of elongated receptacle and young carpels; b) Flower in lateral view showing expanded basal portion of the elongated receptacle and young carpels; c) Flower in longitudinal section showing expanded basal portion of the elongated receptacle and young carpels; note the irregular, possibly expanded stigmatic region (arrow heads), (orthoslice yz0340); d) Flower in lateral view showing attachment scars of tepals (t) and stamens (st) on the expanded basal portion of elongated receptacle and young carpels with possible grooved stigmatic regions (arrow heads); e) Flower in lateral view showing expanded basal portion of elongated receptacle and young carpels; $f$ ) Detail of flower in (e) showing 
virginiensis, this distal portion of the carpels sometimes appears grooved and indistinctly bifid (Text-fig. 5f). The Buarcos fossil closely resembles Atlantocarpus virginiensis from the Puddledock flora and differs mainly in the number of carpels: about 50 in Atlantocarpus virginiensis and about 40 in Atlantocarpus sp. The specimen is not sufficiently distinctive to be assigned to a new species, and we assign it to the same genus as Atlantocarpus sp.

Another possibly related fossil from the Vale de Água locality (S101300, Vale de Água sample 141) consists of an elongated receptacle with about 40 spirally arranged scars, probably from abraded or shed carpels (Text-fig. 5g). The pedicellate structure is very similar in shape to Atlantocarpus sp. from Buarcos, but larger, about $2.5 \mathrm{~mm}$ long without the stalk, and may represent a later developmental stage of an Atlantocarpus-like flower. It is here referred to as Atlantocarpus? sp.

\section{Discussion}

\section{Comparison with other fossil flowers with apocarpous gynoecia}

Mugideiriflora, Lambertiflora and Atlantocarpus described here all have multicarpellate and apocarpous gynoecia with carpels borne on a short conical to strongly elongated, receptacle. Four other genera of fossil floral structures with apocarpous gynoecia have been formally described from Early Cretaceous mesofossils floras from Portugal: Choffaticarpus E.M.Fris, P.R.CRANE et K.R.Pedersen, Kajanthus M.M.Mendes, G.W.Grimm, PAis et E.M.Fris, Paisia E.M.FriIs, M.M.Mendes et K.R.Pedersen and Reyanthus E.M.FriIs, P.R.Crane et K.R.Pedersen. Five additional forms have also been described from the Early and mid-Cretaceous mesofossil floras of eastern North America: Cecilanthus Herend., J.A.Doyle, P.K.Endress et MAs. TAKAH., Kenilanthus E.M.FriIs, P.R.Crane et K.R.Pedersen, Melloniflora E.M.FrIIS, P.R.CRANE et K.R.PEDERSEN and Virginianthus E.M.FriIs, H.EkLund, K.R.PEDERSEN et P.R.CRANE, including the compressed floral axis of Anacostia? sp. previously described as "cone-like structure associated with Anacostia virginiensis" (Friis et al. 1997: fig. 6). There are also several Early and mid-Cretaceous platanoid floral structures with apocarpous gynoecia from both regions (Friis et al. 1988, Crane et al. 1993, Pedersen et al. 1994).

Kajanthus, Kenilanthus and Paisia are distinguished from the three new genera described here in having cyclic flowers and a small number of carpels (three to five). Flowers of Paisia and Kenilanthus are pentamerous while that of Kajanthus is trimerous. Paisia has pantoporate pollen while Kajanthus and Kenilanthus both have tricolpate pollen (Mendes et al. 2014, Friis et al. 2017b, 2018e). All three genera are thought to be related to early diverging lineages of eudicots. Ranunculaecarpus SAmYLINA from eastern Siberia, a petrified Early Cretaceous floral structure with an apocarpous gynoecium, has a pentamerous, cyclic organization, is also of probable eudicot affinity (Samylina 1960, Manchester et al. 2018). Also, the platanoid flowers have fewer carpels (five) and fewer perianth parts than the three new genera described here. They also have flowers crowded in globose heads and tricolpate/tricolporate pollen (Friis et al. 1988, Crane et al. 1993, Pedersen et al. 1994).

Flowers of Cecilanthus, Choffaticarpus, Melloniflora, Reyanthus and Virginianthus, as well as Anacostia? sp. are all similar to Mugideiriflora, Lambertiflora and Atlantocarpus in having an apocarpous gynoecium with many carpels. However, among these taxa, there is considerable variation in how the carpels are borne. In Virginianthus, the carpels are borne on the inside of a cup-shaped hypanthium, whereas in Melloniflora the floral receptacle is almost flat, very different from the elongated receptacle of Atlantocarpus and lacking the short conical gynoecial projection seen in Mugideiriflora and Lambertiflora. In Cecilanthus the receptacle is broad, dome-shaped and bears many more floral parts than in Mugideiriflora, Lambertiflora and Atlantocarpus (Herendeen et al. 2016).

In Choffaticarpus, Reyanthus and Anacostia? sp. the receptacle is more prominently elongated than in Mugideiriflora and Lambertiflora and more like that of Atlantocarpus (Friis et al. 2019a). Among these three fossil forms, Atlantocarpus is most similar to Reyanthus in size and numbers of parts, although in Reyanthus the carpels appear follicular with many ovules, rather than apparently ascidiate as in Atlantocarpus.

Choffaticarpus and Anacostia? sp. (Text-fig. 6a-b) differ from Atlantocarpus in their longer and much broader receptacle and more densely crowded carpels. Their larger size could perhaps be explained by differences in maturity. A smaller carpel-bearing receptacle from the Puddledock flora that is very similar to Atlantocarpus virginiensis but that has many more carpels (Text-fig. 6c) may be an early developmental stage of an Anacostia flower.

Several floral structures with apocarpous gynoecia have also been described from the Early and mid-Cretaceous based on impression-compression fossils, but none are closely comparable to the three genera described here. Archaeanthus linnenbergeri DILCHER et P.R.CRANE from the mid-Cretaceous of Kansas is distinguished by its much larger size, the distinctly plicate carpels and the very long and narrow fruiting receptacle (Dilcher and Crane 1984). Archaeanthus is also distinguished from Mugideiriflora and Lambertiflora by its lower number of perianth parts and in this respect is more similar to Atlantocarpus. Dilcher and Crane (1984) suggested close relationship to members of extant Magnoliaceae, which was also supported by a later analysis of Doyle and Endress (2010). Sinocarpus decussatus LENG et E.M.FriIs from the Early Cretaceous Jehol Biota, Liaoning, China, as well as Hyrcantha karatscheensis (VACHR.) KRASSILOV and Ternaricarpites floribundus Krassilov et Volynets from the early-middle

numerous poorly differentiated carpels some with a poorly differentiated, slightly expanded and possibly grooved stigmatic region (arrow heads); g) Atlantocarpus? sp., elongated receptacle showing expanded basal portion and scars from probable shed fruitlets, perhaps a later developmental stage of Atlantocarpus sp. Scale bars $=1 \mathrm{~mm}(\mathrm{a}-\mathrm{c}, \mathrm{e}, \mathrm{g}), \mathbf{5 0 0} \mu \mathrm{m}(\mathrm{d}, \mathrm{f})$. 

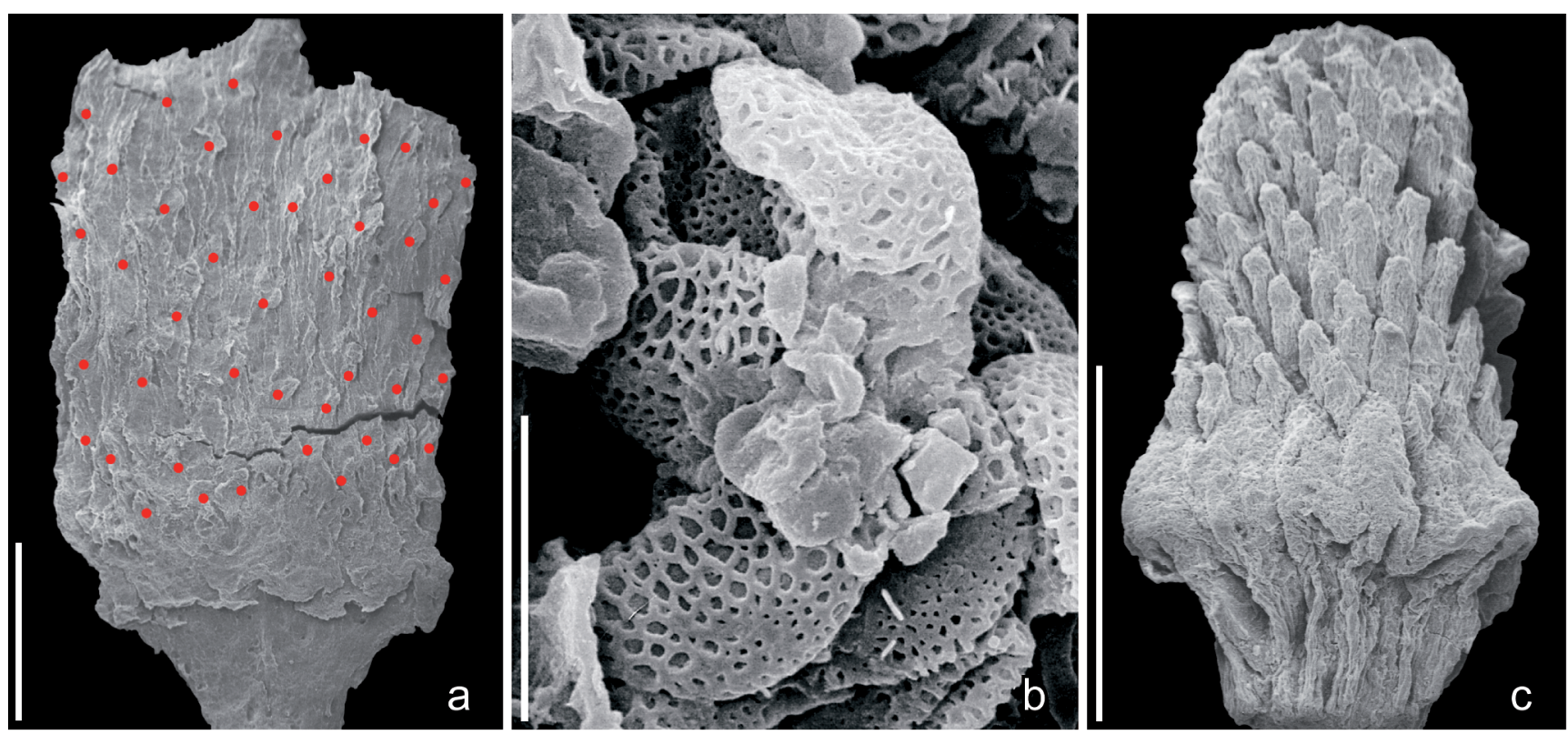

Text-fig. 6. Scanning electron micrographs of multicarpellate and apocarpous floral structures from the Early Cretaceous Puddledock locality, Virginia, USA (a, b: PP43701, Puddledock sample 001; c: PP43000x, Puddledock sample 073). a) Anacostia? sp., strongly compressed, elongated receptacle with spirally arranged carpels (red dots; not all shown); note larger size compared to the other floral structures; b) Numerous Anacostia type pollen grains in proximal view from the base of floral structure in (a); note graded reticulum over the proximal pole of the pollen grains; c) Elongated receptacle with numerous carpels in a spiral arrangement, possibly representing an earlier developmental stage of Anacostia? sp. Scale bars $=1 \mathrm{~mm}(\mathrm{a}, \mathrm{c}), 10 \mu \mathrm{m}(\mathrm{b})$.

Albian of the Primorye Region, Russian Far East, Russia, and several other impression/compression floral structures described from eastern Siberia all have fewer, follicular carpels borne on a flattened receptacle and are thought to represent early eudicots (Krassilov et al. 1983, Leng and Friis 2003, Krassilov and Volynets 2008, Friis et al. 2011).

Two magnolialean floral structures from the Early Cretaceous of Brazil, Endressinia B.A.R.MoHR et BernARdes-De-Oliveira and Schenkeriphyllum B.A.R. Mohr, Coiffard et Bernardes-De-Oliveira both have a flattened floral receptacle and plicate carpels with many ovules (Mohr and Bernardes-de-Oliveira 2004, Mohr et al. 2013). The nymphaealean Pluricarpellatia B.A.R.Mohr, Bernardes-De-Oliveira et DAVID W.TAYlor, also from the Early Cretaceous of Brazil, has a flattened floral receptacle and many ovules per carpels (Mohr et al. 2008).

Mugideiriflora, Lambertiflora and Atlantocarpus are also distinct from the several apocarpous, multicarpellate flowers described from Late Cretaceous floras. The petrified flowers of Protomonimia kasai-nakajhongii H.NisHIDA et M.NISHIDA from the Late Cretaceous of Hokkaido, Japan, are much larger with plicate carpels that mature into follicles bearing numerous seeds and carpels borne on a shallow floral receptacle (Nishida and Nishida 1988). Litocarpon beardii Delev. et Mickle from the Late Cretaceous of British Columbia (Delevoryas and Mickle 1995) is also petrified and also much larger than the flowers described here. Like Archaeanthus linnenbergeri it is probably also an early relative of extant Magnoliaceae.

Among Late Cretaceous three-dimensionally preserved coalified flowers Futabanthus asamigawaensis MAs.TAKAH., E.M.Fris, Uesugi, Yosh.SuzuKi et P.R.Crane from the Late Cretaceous of Japan (Takahashi et al. 2008) differs from the Early Cretaceous fossils described here in its much more numerous floral parts, while Cronquistiflora sayrevillensis CREPET et NiXon, Detrusandra mystagoga CREPET et NixON and Jerseyanthus calycanthoides CREPET, NiXON et GANDOLFO described from the Late Cretaceous of New Jersey (Crepet and Nixon 1998, Crepet et al. 2005) also differ from the Early Cretaceous taxa in several respects. In Cronquistiflora sayrevillensis the receptacle forms a shallow cup, which is still more pronounced in Detrusandra mystagoga and in Jerseyanthus calycanthoides. There are also several platanoid taxa described from the Late Cretaceous mesofossil floras from Europe and North America (e.g., Friis et al. 1988, Magallón-Puebla et al. 1997), but these are distinguished from the fossils described here in their fewer parts and arrangements in dense spherical inflorescences.

\section{Systematic relationships of Mugideiriflora, Lambertiflora and Atlantocarpus}

None of the floral structures described here provides information on all floral organs and none has pollen grains in situ or adhering to the surface of flower parts. In all three genera, carpels are preserved at early or very early developmental stages and information on ovules are not available for any of the taxa. Further, information on the form and number of the pollen sacs and their mode of dehiscence is missing or incomplete for all three genera.

In Mugideiriflora and Lambertiflora information on the number and arrangement of floral parts can be inferred from SEM and SRXTM data that show many perianth parts arranged spirally in several series. For all three genera, the apocarpous nature of the gynoecium, the presence of many carpels in a spiral arrangement and the elongate floral receptacle strongly indicate affinity with angiosperms at the level of Austrobaileyales or Magnoliales. However, 


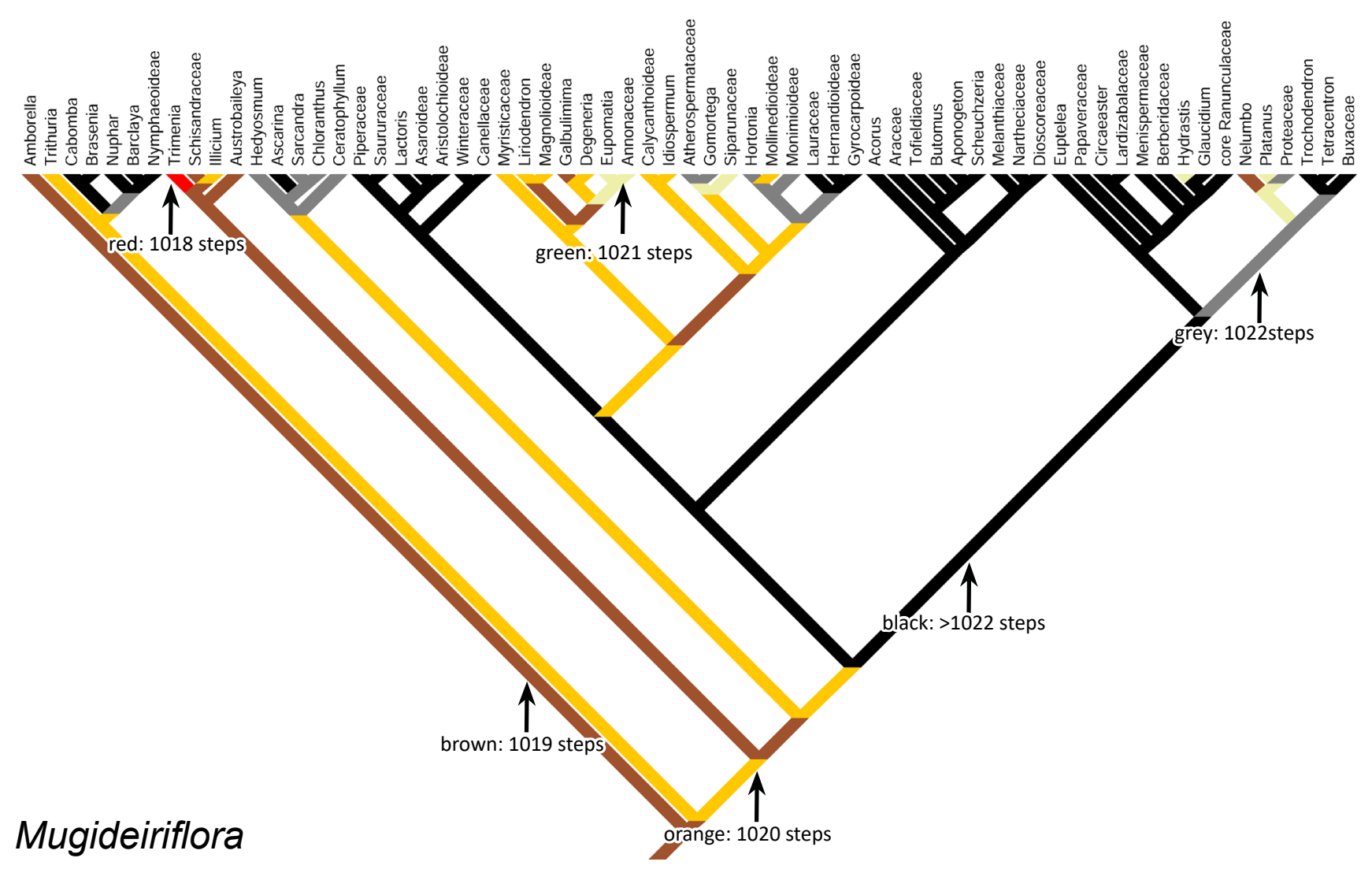

Text-fig. 7. Number of required character state changes under parsimony (steps) for various positions of Mugideiriflora portugallica, based on the Doyle and Endress character matrix and backbone tree (Doyle and Endress 2000, 2014).

the fossils cannot be placed securely in the angiosperm phylogenetic tree based on the information available.

Among extant angiosperm lineages included in the Doyle and Endress $(2000,2014)$ analysis, an elongate gynoecial zone in the floral receptacle, as seen in Mugideiriflora, Lambertiflora and Atlantocarpus, is only recorded for Austrobaileyales (Schisandra MichX.) and Magnoliales (Magnoliaceae and Galbulimima F.M.BAILEY). Among Austrobaileyales and Magnoliales spiral phyllotaxis of the perianth as recorded for Mugideiriflora and Lambertiflora is characteristic for Austrobaileyales and only recorded in the Magnoliales for Degeneria I.W.BAILEY et A.C.SM. Similarly, the ascidiate carpels inferred for Atlantocarpus are known only for Austrobaileyales (plicate in Illicium) while carpels in Magnoliales are plicate (intermediate ascidiate in Myristicaceae, uncertain in Eupomatia; Doyle and Endress 2000, 2014).

Phylogenetic assessments of all three fossil genera also indicate close similarity with extant members of Austrobaileyales and Magnoliales, although there are similarities to other groups and the phylogenetic signal is not strong (Text-figs 7-9). For Mugideiriflora, a position as sister to Trimenia SeEm. (Austrobaileyales) requires 1,018 steps, but a position as sister to Schisandra, Austrobaileya C.T.White or to Austrobaileyales as a whole, is only one step longer, as also is a position as sister to all angiosperms, Amborella BAILL., Magnoliaceae, Laurales and Nelumbo ADANS. Several other positions among early diverging angiosperms and Magnoliales require only one or a few additional steps (Text-fig. 7).
There are three most parsimonious positions for Lambertiflora: sister to Trimenia, sister to Schisandra and sister to Galbulimima (1,017 steps), while a sister group relation to all angiosperms, to Amborella, and to several lineages among Magnoliales and Laurales, as well as Nelumbo, is only one step longer (Text-fig. 8).

For Atlantocarpus the most parsimonious position is as sister to Schisandra (Text-fig. 9). A sister relation to Trimenia, Illicium L. and Austrobaileya, and also Austrobaileyales as a whole, is only one step longer as is a position as sister to Nelumbo. A further step is required for a sister position to all angiosperms, and to several ANA-grade angiosperms as well as to several members of Magnoliales and to Mollinedioideae (Laurales). A position as sister to Schisandra is supported particularly by the elongated gynoecial zone of the receptacle and the inferred ascidiate carpels.

Further support for a possible relationship of Atlantocarpus to Austrobaileyales is the similarity to gynoecium of Anacostia? sp. This fossil is linked to isolated fruits of Anacostia by the presence of abundant Anacostia type pollen on the staminate zone of the receptacle below the carpels, as well as strong similarity in epidermal features of the isolated fruits and the compressed fruits borne on the fertile axis the cone (Text-fig. 6a, b). However, Anacostia? sp. differs from Atlantocarpus in its greater number of carpels and much longer receptacle. Another similar fertile axis from the Puddledock locality (Text-fig. 6c) with similarities to Atlantocarpus in general organization, but with a higher number of carpels, may represent an early developmental stage of an Anacostia flower. 


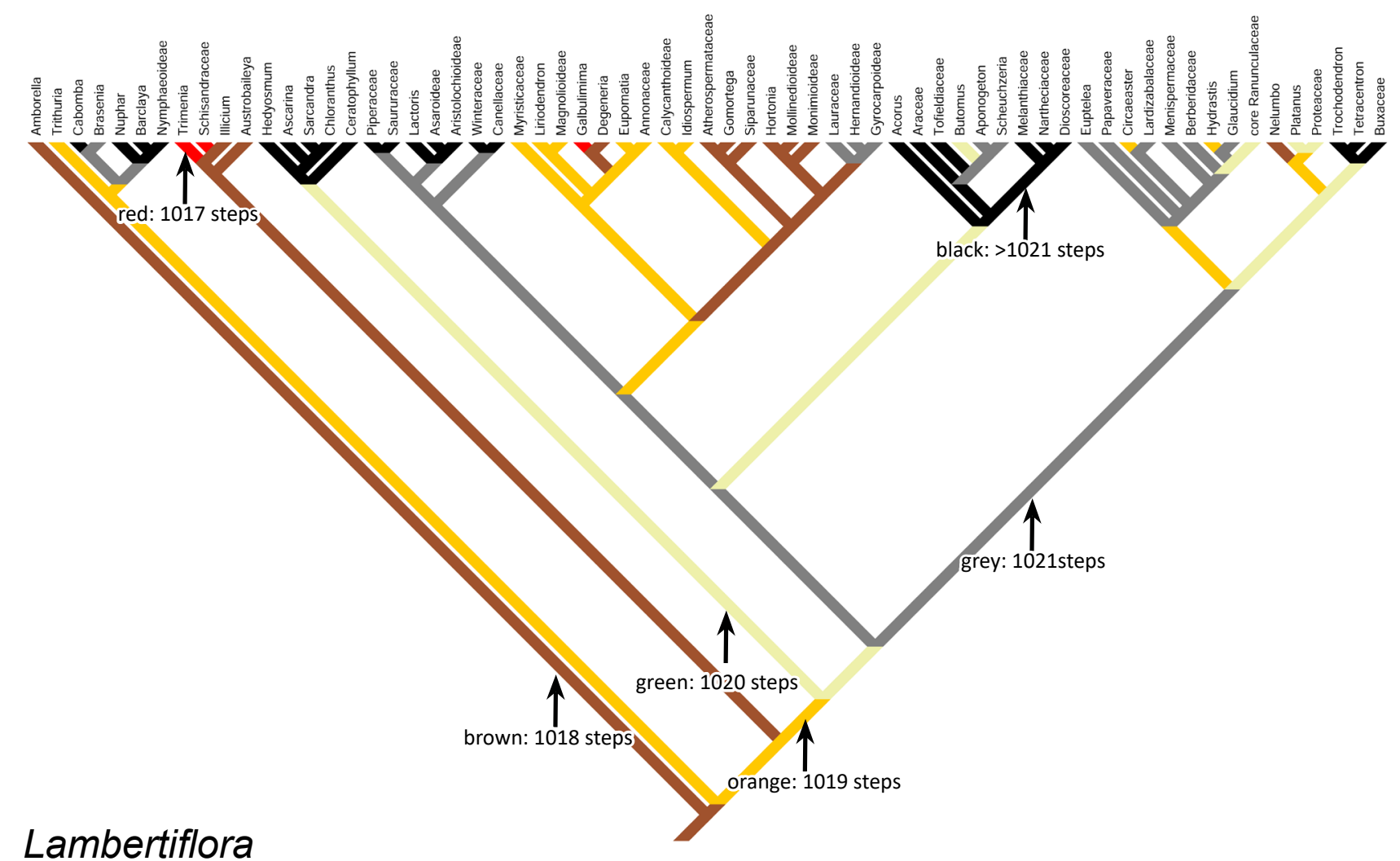

Text-fig. 8. Number of required character state changes under parsimony (steps) for various positions of Lambertiflora elegans, based on the Doyle and Endress character matrix and backbone tree (Doyle and Endress 2000, 2014).

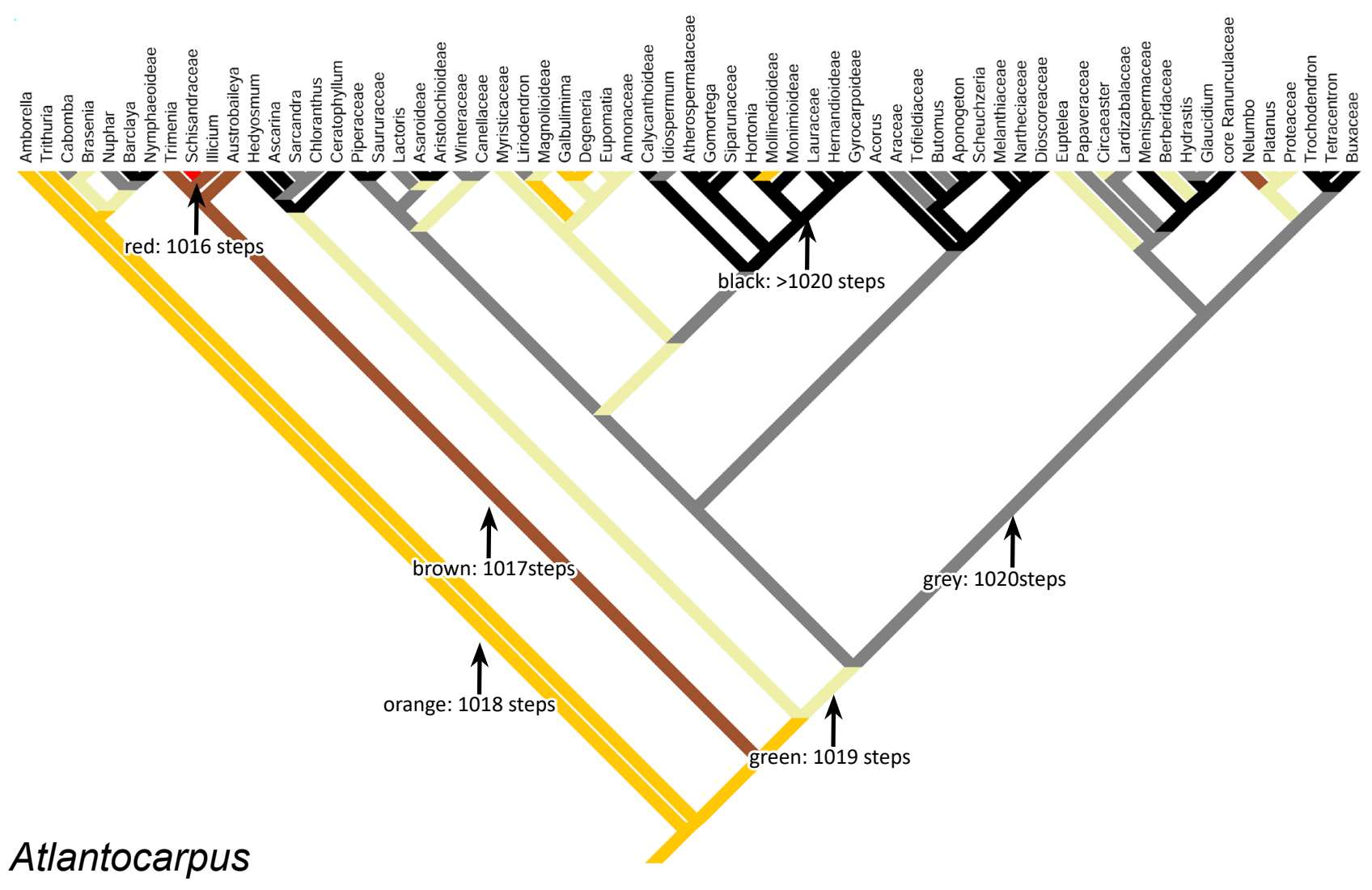

Text-fig. 9. Number of required character state changes under parsimony (steps) for various positions of Atlantocarpus virginiensis, based on the Doyle and Endress character matrix and backbone tree (Doyle and Endress 2000, 2014). 
A relationship between Anacostia and extant Schisandra and Kadsura KAEMPF. ex Juss. (Schisandraceae) was discussed by Friis et al. (1997), but a relationship with certain monocots was also considered, mainly because of the trichotomocolpate pollen with a semi-tectate, reticulate and graded tectum. A monocot affinity for Anacostia is now refuted by the recognition of embryos with two cotyledons in seeds of Anacostia (Friis et al. 2015b). A close relationship between Anacostia and Schisandraceae was also supported by Doyle and Endress (2010).

The presence of extinct plants closely related to extant ANA-grade angiosperms early in angiosperm history is also supported by the diversity of exotestal seeds described from the Early Cretaceous mesofossil floras of eastern North America and Portugal. The seeds occur both isolated and in one- or two-seeded fruits. Several of these seeds, including species of Gastonispermum E.M.FrIIS, P.R.Crane et K.R.Pedersen, Lusitanispermum E.M.Fris, P.R.Crane et K.R.Pedersen, Nitaspermum E.M.Fris, P.R.Crane et K.R.Pedersen, Pazlia E.M.Fris, P.R.Crane et K.R.Pedersen, Pazliopsis E.M.Fris, P.R.Crane et K.R.Pedersen, Reyispermum E.M.FriIs, P.R.Crane et K.R.Pedersen, Silutanispermum E.M.Friss, P.R.Crane et K.R.Pedersen and Tanispermum E.M.Fris, P.R.Crane et K.R.Pedersen show features characteristic of Nymphaeales and Austrobaileyales (Friis et al. 2018a, b, c).

\section{Conclusions}

Mugideiriflora, Lambertiflora and Atlantocarpus add to the diversity of apocarpous flowers known from the early phases of angiosperm diversification during the middle of the Early Cretaceous. They also illustrate considerable variation in the form of the receptacle, as well as the number and arrangement of floral parts. The lack of information on many key characters precludes full comparison with potential extant relatives, as was also the case for several distinctive exotestal seeds described from the Early Cretaceous mesofossil floras of Portugal and eastern North America. The relationships of all three taxa, however, appear likely to be with extant Austrobaileyales, recognizing that a variety of relationships to other ANA or magnoliid taxa are only slightly less parsimonious.

Also contributing to the difficulty of establishing the relationships of these Early Cretaceous flowers is the probability that many of the features they exhibit are likely plesiomorphic for early angiosperms as a whole. Against this background understanding the precise pattern of evolution of potential synapomorphies, for example, the elongation of the gynoecial zone of the receptacle seen in all three taxa, is especially important. This will require more critical analysis of potential homologies and homoplasy than is possible with datasets currently available for this portion of the angiosperm phylogenetic tree. Given evidence of extensive extinction among ANA and magnoliid lineages over the last 100 million years there is also the broader question of whether phylogenetic patterns can be reliably inferred for the earliest phases of angiosperm evolution based solely on the relatively few, systematically depauperate, taxa that remain extant in these ancient lineages.

\section{Acknowledgements}

We thank the Paul Scherrer Institut, Villigen, Switzerland, for provision of synchrotron radiation beamtime at the TOMCAT beamline X02DA of the Swiss Light Source. We are also grateful to Federica Marone for her help at the beamline (projects 20080872 and 20130185 to P. C. J. Donoghue, S. Bengtson, E. M. Friis and M. Rücklin) and Anna Lindström for help with the SRXTM analyses. Jiří Kvaček and Steven R. Manchester are thanked for valuable comments on the manuscript. Support for this research was also obtained from the Swedish Research Council (2014-5228 to E. M. Friis) and from the Oak Spring Garden Foundation.

\section{References}

von Balthazar, M., Crane, P. R., Pedersen, K. R. Friis, E. M. (2011): New flowers of Laurales from the Early Cretaceous (Early to Middle Albian) of eastern North America. - In: Ronse De Craene, L. P., Wanntorp, L. (eds), The rediscovery of floral morphology in phylogenetics. Cambridge University Press, Cambridge, pp. 49-87.

https://doi.org/10.1017/CBO9781139013321.003

von Balthazar, M., Pedersen, K. R., Crane, P. R., Friis, E. M. (2008): Carpestella lacunata gen. et sp. nov., a new basal angiosperm flower from the Early Cretaceous (early to middle Albian) of eastern North America. - International Journal of Plant Sciences, 169: 890-898.

https://doi.org/10.1086/589692

von Balthazar, M., Pedersen, K. R., Crane, P. R., Stampanoni, M., Friis, E. M. (2007): Potomacanthus lobatus gen. et sp. nov., a new flower of probable Lauraceae from the Early Cretaceous (Early to Middle Albian) of Eastern North America. - American Journal of Botany, 94: 2041-2053. https://doi.org/10.3732/ajb.94.12.2041

von Balthazar, M., Pedersen, K. R., Friis, E. M. (2005): Teixeiraea lusitanica, a new fossil flower from the Early Cretaceous of Portugal with affinities to Ranunculales. Plant Systematics and Evolution, 255: 55-75. https://doi.org/10.1007/s00606-005-0347-z

Crane, P. R., Lidgard, S. (1989): Angiosperm diversification and paleolatitudinal gradients in Cretaceous floristic diversity. - Science, 246: 675-678. https://doi.org/10.1126/science.246.4930.675

Crane, P. R., Pedersen, K. R., Friis, E. M., Drinnan, A. N. (1993): Early Cretaceous (early to middle Albian) platanoid inflorescences associated with Sapindopsis leaves from the Potomac Group of eastern North America. - Systematic Botany, 18: 328-344. https://doi.org/10.2307/2419407

Crepet, W. L., Nixon, K. C. (1998): Two new fossil flowers of magnoliid affinity from the Late Cretaceous of New Jersey. - American Journal of Botany, 85: 1273-88. https://doi.org/10.2307/2446638

Crepet, W. L. , Nixon, K. C., Gandolfo, M. A. (2005): An extinct calycanthoid taxon, Jerseyanthus calycanthoides, from the Late Cretaceous of New Jersey. - American Journal of Botany, 92: 1475-1485.

https://doi.org/10.3732/ajb.92.9.1475 
Delevoryas, T., Mickle, J. E. (1995): Upper Cretaceous magnoliaceous fruit from British Columbia. - American Journal of Botany, 82: 763-768. https://doi.org/10.1002/j.1537-2197.1995.tb15688.x

Dilcher, D. L., Crane, P. R. (1984): Archaeanthus: An early angiosperm from the Cenomanian of the Western Interior of North America. - Annals of the Missouri Botanical Garden, 71: 351-383. https://doi.org/10.2307/2399030

Dinis, J. L. (2001): Definição da Formação da Figueira da Foz - Aptiano a Cenomaniano do sector central da margem oeste ibérica [Definition of the Figueira da Foz Formation - Aptian to Cenomanian of the central sector of the western Iberian margin]. - Comunicações Instituto Geológico e Mineiro, 88: 127-160. (in Portuguese)

Dinis, J. L., Rey, J., Cunha, P. P., Callapez, P., Pena Dos Reis, R. (2008): Stratigraphy and allogenic controls of the western Portugal Cretaceous: an updated synthesis. Cretaceous Research, 29: 772-780. https://doi.org/10.1016/j.cretres.2008.05.027

Dinis, J. L., Oliveira, F. P., Rey, J., Duarte, I. L. (2010): Finding geological heritage: Legal issues on private property and fieldwork. The case of outstanding early angiosperms (Barremian to Albian, Portugal). Geoheritage, 2: 77-90. https://doi.org/10.1007/s12371-010-0013-x

Dischinger, J. B. (1987): Late Mesozoic and Cenozoic stratigraphic and structural framework near Hopewell, Virginia. - US Geological Survey Bulletin, 1567: 1-48.

Doyle, J. A., Endress, P. K. (2000): Morphological phylogenetic analysis of basal angiosperms: comparison and combination with molecular data. - International Journal of Plant Sciences, 161(6 suppl.): S121-S153. https://doi.org/10.1086/317578

Doyle, J. A., Endress, P. K. (2010): Integrating Early Cretaceous fossils into the phylogeny of living angiosperms: Magnoliidae and eudicots. - Journal of Systematic Evolution, 48: 1-35. https://doi.org/10.1111/j.1759-6831.2009.00058.x

Doyle, J. A., Endress, P. K. (2014): Integrating Early Cretaceous fossils into the phylogeny of living angiosperms: ANITA lines and relatives of Chloranthaceae. International Journal of Plant Sciences, 175: 555-600. https://doi.org/10.1086/675935

Friis, E. M., Crane, P. R., Pedersen, K. R. (1988): Reproductive structure of Cretaceous Platanaceae. - Biologiske Skrifter Det Kongelige Danske Videnskabernes Selskab, 31: 1-56.

Friis, E. M., Crane, P. R., Pedersen, K. R. (1997): Anacostia, a new basal angiosperm from the Early Cretaceous of North America and Portugal with trichotomocolpate/ monocolpate pollen. - Grana, 36: 225-244. https://doi.org/10.1080/00173139709362611

Friis, E. M., Crane, P. R., Pedersen, K. R. (2011): Early flowers and angiosperm evolution. - Cambridge University Press, Cambridge, $\mathrm{x}+585 \mathrm{pp}$. https://doi.org/10.1017/CBO9780511980206

Friis, E. M., Crane, P. R., Pedersen, K. R. (2017a): Saportanthus, an extinct genus of Laurales from the Early Cretaceous of Portugal. - International Journal of Plant Sciences, 78: 650-672. https://doi.org/10.1086/693108
Friis, E. M., Crane, P. R., Pedersen, K. R. (2017b): Kenilanthus, a new eudicot flower with tricolpate pollen from the Early Cretaceous (early-middle Albian) of eastern North America. - Grana, 56: 161-173. https://doi.org/10.1080/00173134.2016.1158863

Friis, E. M., Crane, P. R., Pedersen, K. R. (2018a): Fossil seeds with affinities to Austrobaileyales and Nymphaeales from the Early Cretaceous (early-middle Albian) of Virginia and Maryland, U.S.A: new evidence for extensive extinction near the base of the angiosperm tree. - In: Krings, M., Harper, C. J., Cúneo, N. R., Rothwell, G. W. (eds), Transformative Paleobotany: Papers to Commemorate the Life and Legacy of Thomas N. Taylor. Academic Press, Burlington, MA, pp. 417-435.

https://doi.org/10.1016/B978-0-12-813012-4.00017-6

Friis, E. M., Crane, P. R., Pedersen, K. R. (2018b): Tanispermum, a new genus of hemi-orthotropous to hemianatropous angiosperm seeds from the Early Cretaceous of eastern North America. - American Journal of Botany, 105: 1369-1388. https://doi.org/10.1002/ajb2.1124

Friis, E. M., Crane, P. R., Pedersen, K. R. (2018c): Extinct taxa of exotestal seeds close to Austrobaileyales and Nymphaeales from the Early Cretaceous of Portugal. Fossil Imprint, 74: 135-158. https://doi.org/10.2478/if-2018-0010

Friis, E. M., Crane, P. R., Pedersen, K. R. (2018d): Rightcania and Kvacekispermum: Early Cretaceous seeds from eastern North America and Portugal provide further evidence of the early chloranthoid diversification. Fossil Imprint, 74: 65-76. https://doi.org/10.2478/if-2018-0006

Friis, E. M., Crane, P. R., Pedersen, K. R. (2019a): The Early Cretaceous mesofossil flora of Torres Vedras (NE of Forte da Forca), Portugal: a palaeofloristic analysis of an early angiosperm community. - Fossil Imprint, 75: $153-257$. https://doi.org/10.2478/if-2019-0013

Friis, E. M., Crane, P. R., Pedersen, K. R. (2019b): Extinct diversity among Early Cretaceous angiosperms: mesofossil evidence of early Magnoliales from Portugal. - International Journal of Plant Sciences, 180: 93-127. https://doi.org/10.1086/701319

Friis, E. M., Crane, P. R., Pedersen, K. R. (2019c): Hedyosmum-like fossils in the Early Cretaceous diversification of angiosperms. - International Journal of Plant Sciences, 180: 232-239. https://doi.org/10.1086/701819

Friis, E. M., Crane, P. R., Pedersen, K. R. (2020a): Melloniflora, a new extinct multiparted flower from the Early Cretaceous of Virginia, USA. - International Journal of Plant Sciences, 181(9): 887-897. https://doi.org/10.1086/710490

Friis, E. M., Crane, P. R., Pedersen, K. R. (2021): Catanthus, an extinct magnoliid flower from the Early Cretaceous of Portugal. - International Journal of Plant Sciences, 182(1): 28-45. [as effective publication published online on November 25, 2020] https://doi.org/10.1086/711081

Friis, E. M., Crane, P. R., Pedersen, K. R., Marone, F. (2020b): Synchrotron radiation X-ray tomographic 
microscopy datasets for Atlantocarpus, Lambertiflora and Mugideiriflora from the Early Cretaceous of eastern North America and Portugal; on-line available datasets. - PSI Public Data Repository, operated by Paul Scherrer Institute, Villigen, Switzerland.

https://doi.org/10.16907/c01b594e-e42e-45f9-913e$5001 \mathrm{fd} 283 \mathrm{aee}$

Friis, E. M., Crane, P. R., Pedersen, K. R., Stampanoni, M., Marone, F. (2015b): Exceptional preservation of tiny embryos documents seed dormancy in early angiosperms. - Nature, 528: 551-554.

https://doi.org/10.1038/nature16441

Friis, E. M., Eklund, H., Pedersen, K. R. Crane, P. R. (1994): Virginianthus calycanthoides gen. et sp. nov. - A Calycanthaceous Flower from the Potomac Group (Early Cretaceous) of Eastern North America. - International Journal of Plant Sciences, 155: 772-785.

https://doi.org/10.1086/297217

Friis, E. M., Grimm, G. W., Mendes, M. M., Pedersen, K. R. (2015a): Canrightiopsis, a new Early Cretaceous fossil with Clavatipollenites-type pollen bridge the gap between extinct Canrightia and extant Chloranthaceae. Grana, 54: 184-212.

https://doi.org/10.1080/00173134.2015.1060750

Friis, E. M., Marone, F., Pedersen, K. R., Crane, P. R., Stampanoni, M. (2014): Three-dimensional visualization of fossil flowers, fruits, seeds and other plant remains using synchrotron radiation $\mathrm{X}$-ray tomographic microscopy (SRXTM): New insights into Cretaceous plant diversity. - Journal of Paleontology, 88: 684-701. https://doi.org/10.1666/13-099

Friis, E. M., Mendes, M. M., Pedersen, K. R. (2018e). Paisia, an Early Cretaceous eudicot angiosperm flower with pantoporate pollen from Portugal. - Grana 57: 1-15. https://doi.org/10.1080/00173134.2017.1310292

Friis, E. M., Pedersen, K. R., von Balthazar, M., Grimm, G. W., Crane, P. R. (2009): Monetianthus mirus gen. et sp. nov., a Nymphaealean flower from the Early Cretaceous of Portugal. - International Journal of Plant Science, 170: 1086-1101.

https://doi.org/10.1086/605120

Herendeen, P. S., Doyle, J. A., Endress, P. K., Takahashi, M. (2016): Cecilanthus polymerus, a novel multiparted flower from the mid-Cretaceous Rocky Point locality, Maryland. - Botany 94: 787-803.

https://doi.org/10.1139/cjb-2016-0039

Krassilov, V. A., Shilin, P. V., Vachrameev, V. A. (1983): Cretaceous flowers from Kazakhstan. - Review of Palaeobotany and Palynology, 40: 91-113. https://doi.org/10.1016/0034-6667(83)90005-2

Krassilov, V. A., Volynets, J. (2008): Weedy Albian angiosperms. - Acta Palaeobotanica, 48: 151-169.

Leng, Q., Friis, E. M. (2003): Sinocarpus decussatus gen. et sp. nov., a new angiosperm with syncarpous fruits from the Yixian Formation of Northeast China. - Plant Systematics and Evolution, 241: 77-88. https://doi.org/10.1007/s00606-003-0028-8

Maddison, W. P., Maddison, D. R. (2017): Mesquite: a modular system for evolutionary analysis. - Version 3.2. http://mesquiteproject.org
Magallón, S., Crane, P. R., Herendeen, P. S. (1999): Phylogenetic pattern, diversity, and diversification of eudicots. - Annals of the Missouri Botanical Garden, 86: 297-372. https://doi.org/10.2307/2666180

Magallón-Puebla, S., Herendeen, P. S., Crane, P. R. (1998): Quadriplatanus georgianus gen. et sp. nov.: staminate and pistillate platanaceous flowers from the Late Cretaceous (Coniacian-Santonian) of Georgia, U.S.A. International Journal of Plant Sciences, 158: 373-394. https://doi.org/10.1086/297448

Manchester, S. R., Goloneva, L. B., Sokoloff, D. D., Friis, E. M. (2018): Early eudicot reproductive structure: Fruit and flower morphology of Ranunculaecarpus Samyl. from the Early Cretaceous of eastern Siberia. - Acta Palaeobotanica Polonica, 58: 121-133. https://doi.org/10.2478/acpa-2018-0017

Mendes, M. M., Friis, E. M., Pedersen, K. R. (2020): Battenispermum hirsutum gen. et sp. nov., a new Early Cretaceous seed from Portugal with chlamydospermous organisation. - Cretaceous Research, 109: 104376 (8 pp). https://doi.org/10.1016/j.cretres.2020.104376

Mendes, M. M., Grimm, G. W., Pais, J., Friis, E. M. (2014): Fossil Kajanthus lusitanicus gen. et sp. nov. from Portugal: floral evidence for Early Cretaceous Lardizabalaceae (Ranunculales, basal eudicot). - Grana, 53, 283-301. https://doi.org/10.1080/00173134.2014.932431

Mohr, B. A. R, Bernardes-de-Oliveira, M. E. C. (2004): Endressinia brasiliana, a magnolialean angiosperm from the Lower Cretaceous Crato Formation (Brazil). International Journal of Plant Sciences, 165: 1121-1133. https://doi.org/10.1086/423879

Mohr, B. A. R., Bernardes-de-Oliveira, M. E. C., Taylor, D. W. (2008): Pluricarpellatia, a nymphaealean angiosperm from the Lower Cretaceous of northern Gondwana (Crato Formation, Brazil). - Taxon, 57: 1147-1158. https://doi.org/10.1002/tax.574009

Mohr, B. A. R., Coiffard, C., Bernardes-de-Oliveira, M. E. C. (2013): Schenkeriphyllum glanduliferum, a new magnolialean angiosperm from the Early Cretaceous of Northern Gondwana and its relationships to fossil and modern Magnoliales. - Review of Palaebotany and Palynology, 189: 57-72.

https://doi.org/10.1016/j.revpalbo.2012.08.004

Nishida, H., Nishida, M. (1988): Protomonimia kasainakajhongii gen. et sp. nov.: a permineralized magnolialean fructification from the mid-Cretaceous of Japan. - Botanical Magazine of Tokyo, 101: 397-426. https://doi.org/10.1007/BF02488085

Pedersen, K. R., von Balthazar, M., Crane, P. R., Friis, E. M. (2007): Early Cretaceous floral structures and in situ tricolpate-striate pollen: New early eudicots fromPortugal. - Grana, 46: 176-196. https://doi.org/10.1080/00173130701526507

Pedersen, K. R., Friis, E. M., Crane, P. R., Drinnan, A. N. (1994): Reproductive structures of an extinct platanoid from the Early Cretaceous (latest Albian) of eastern North America. - Review of Palaeobotany and Palynology, 80: 291-303. https://doi.org/10.1016/0034-6667(94)90006-X 
Samylina, V. A. (1960): Pokrytosemennye iz nizhnemelovykh otlozheniy Kolymi [Angiosperms from the Lower Cretaceous deposits of Kolyma]. - Botanicheskiy Zhurnal, 45: 335-352. (in Russian)

Stampanoni, M., Groso, A., Isenegger, A., Mikuljan, G., Chen, Q., Bertrand, A., Henein, S., Betemps, R., Frommherz, U., Bohler, P., Meister, D., Lange, M., Abela, A. (2006): Trends in synchrotron-based tomographic imaging: the SLS experience. - In: Bonse, U. (ed.),
Developments in X-Ray Tomography V. Proceedings of SPIE-The International Society for Optical Engineering, San Diego, 6318: 63180M (14 pp.). https://doi.org/10.1117/12.679497

Takahashi, M., Friis, E. M., Uesugi, K., Suzuki, Y., Crane, P. R. (2008): Floral evidence of Annonaceae from the Late Cretaceous of Japan. - International Journal of Plant Sciences, 169: 899-907.

https://doi.org/10.1086/589933 